\title{
SÚMULA 381: O DESSERVIÇO DO SUPERIOR TRIBUNAL DE JUSTIÇA À DEFESA DO CONSUMIDOR
}

\section{PRECEDENTE 381: MAL SERVICIO PRESTADO POR EL TRIBUNAL DE LA CORTE SUPERIOR PARA PROTECCIÓN DE LOS CONSUMIDORES}

\begin{abstract}
${ }^{1}$ Leonardo Macedo Poli
${ }^{2}$ Sérgio Augusto Pereira Lorentino

\section{RESUMO}

Cabe ao Superior Tribunal de Justiça, STJ, a interpretação da legislação federal, especialmente, no caso específico, tratado no presente artigo, das normas de defesa do consumidor. No ano de 2009, o STJ publicou a Súmula 381 que veda o conhecimento de ofício por parte do Juiz, de cláusula abusiva em contratos bancários. Assim, o estudo analisa a constitucionalidade do entendimento sumular, bem como a correta interpretação dada à Lei 8.078/94, que dispõe sobre a proteção e defesa do consumidor, enquanto norma de inspiração constitucional, com natureza de norma de ordem pública e interesse social. Ademais, o estudo também contempla uma análise crítica da referida súmula no tocante à menção da impossibilidade de conhecimento de ofício de abusividade, especificamente nos contratos de natureza bancária. $\mathrm{O}$ estudo fará a abordagem tendo em vista a natureza jurídica da relação de consumo, bem como as peculiaridades do sujeito consumerista e a necessidade de atuação jurisdicional voltada para a efetiva proteção do consumidor contratante como meta de Estado e não apenas como decorrência de ação voluntária da parte autora dentro do processo civil.
\end{abstract}

Palavras-chave: Súmula 381, Stj, Inconstitucionalidade, Prejuízo, Defesa, Consumidor

\section{RESUMEN}

Corresponde al Tribunal Superior de Justicia, STJ, la interpretación de la legislación federal, sobre todo en el caso concreto tratado en este artículo, las normas de protección del consumidor. En 2009 lo STJ emitió Precedente 381 que sella la carta de conocimiento por parte del Juez de cláusulas abusivas en los contratos bancarios. Así, el estudio examina la constitucionalidad de entendimiento sumular así como la correcta interpretación de la Ley 8.078 / 94, que establece la protección de los consumidores y la protección_ mientras que la regla de inspiración constitucional_con naturaleza de norma de orden público e interés social. Además, el estudio incluye también un análisis crítico de ese precedente en cuanto a la mención de la unconscionability de conocimiento automático es imposible, específicamente en contratos de operaciones bancarias. El estudio hará que el enfoque de la naturaleza jurídica de consumo, así como las peculiaridades de la consumista tema y la necesidad de acción nacional para la protección eficaz de los consumidores contratista como un objetivo de Estado y no sólo como resultado de la acción voluntaria demandante en el caso civil.

Palabras-claves: Precedente 381, Stj, Inconstitucionalidad, Lesión, Defensa, Consumidor

\footnotetext{
${ }^{1}$ Doutor em Direito pela Universidade Federal de Minas Gerais - UFMG, Minas Gerais (Brasil)

Professor pela Universidade Federal de Minas Gerais - UFMG, Minas Gerais (Brasil).

E-mail: leonardopoli@pucminas.br

${ }^{2}$ Doutor em Direito pela Pontifícia Universidade Católica de Minas Gerais - PUC, Minas Gerais (Brasil). Professor de Direito pela Universidade Federal do Tocantins - UFT, Tocantins (Brasil).E-mail: sergiolorentino@uft.edu.br
} 


\section{INTRODUÇÃO}

O objetivo do presente artigo é colocar em discussão diversos aspectos ligados à defesa do consumidor os quais foram, severa e absurdamente, prejudicados pelo Superior Tribunal de Justiça, STJ, quando do édito da Súmula de número 381, que trata da impossibilidade de que o julgador conheça de ofício acerca da abusividade constante em cláusula de contrato bancário.

A argumentação passará pelo estudo da natureza das fontes do Direito do Consumidor e de suas naturezas, especialmente as normativas, com especial foco no Código de Defesa do Consumidor, instituído pela Lei $\mathrm{n}^{\circ}$ 8.078/90, como norma impetuosamente violada pelo referido entendimento sumular.

Será também levada em conta a condição de vulnerabilidade do consumidor, especialmente sua fragilidade frente aos contratos massificados pela economia capitalista contemporânea, bem como, e em função disso, a necessidade de atuação do Estado em prol do sujeito fragilizado.

Ao cabo do estudo, se concretizará uma crítica ao entendimento sumular do STJ com lastro na Declaração Universal dos Direitos Humanos, da Constituição Federal de 1988, do Código de Defesa do Consumidor, bem como na correta hermenêutica aplicável às tensões jurisdicionais havidas entre consumidores e fornecedores

\section{A SÚMULA 381 DO STJ}

A Segunda Seção do STJ entendeu por bem pelo édito da seguinte súmula:

Súmula 381 - Nos contratos bancários, é vedado ao julgador conhecer, de ofício, da abusividade das cláusulas. (Súmula 381, SEGUNDA SEÇÃO, julgado em 22/04/2009, DJe 05/05/2009)

A razão para tanto veio dos procedentes que entendiam que ao conhecer de ofício de cláusulas abusivas, o julgador estaria violando o princípio tantum devolutum quantum appellatum, ao praticar julgamento extra petita, já que conheceria de pedidos e matérias não suscitadas durante as fases iniciais do processo de postulação.

Importa, a bem da compreensão histórica do Tribunal, a observância de alguns dos principais precedentes inspiradores do entendimento sumular em comento: 
A jurisprudência da Segunda Seção consolidou-se no sentido de que fere o princípio do tantum devolutum quantum appellatum a revisão, de ofício, pelo juiz, de cláusulas contratuais que não foram objeto de recurso (REsp n ${ }^{\circ}$ 541.153, RS, Relator o Ministro Cesar Asfor Rocha, DJ de 14.09.2005)." (AgRg nos EREsp 801421 RS, Rel. Ministro ARI PARGENDLER, SEGUNDA SEÇÃ̃O, julgado em 14/03/2007, DJ 16/04/2007, p. 164).

"[...]Embora incidente o Código de Defesa do Consumidor nos contratosbancários, não se admite a revisão, de ofício, das cláusulas contratuais consideradas abusivas. [...] Assiste razão ao recorrente no que concerne à impossibilidade de o órgão julgador revisar as cláusulas contratuaisconsideradas abusivas, a despeito de irresignação da parte interessada, tendo em vista a natureza patrimonial dos direitos envolvidos. Consoante pacífico entendimento no âmbito da Segunda Seção do Superior Tribunal de Justiça, o julgamento realizado de ofício pelo Tribunal ofende o princípio tantum devolutum quantum appellatum positivado no artigo 515 do Código de Processo Civil (CPC), uma vez que a Corte revisora exorbita na entrega da prestação jurisdicional, indo além do que foi impugnado nas razões recursais. Ressalvam-se, por óbvio, as restritas hipóteses emque tal atividade é autorizada." (AgRg no REsp 782895 SC, Rel. Ministro SIDNEI BENETI, TERCEIRA TURMA, julgado em 19/06/2008, DJe 01/07/2008).

"Com relação à alegada ofensa ao art. 515 do CPC, o entendimento mais recente desta egrégia Corte é no sentido da impossibilidade do reconhecimento, de ofício, de nulidade de cláusulas contratuaisconsideradas abusivas, sendo, para tanto, necessário o pedido expresso da parte interessada (ut REsp 612.470/RS, Rel. Ministra Nancy Andrighi, DJ 30.06.2006). Assinala-se, ainda, que, nos termos do artigo 515 do CPC, excetuando-se as matérias de ordem pública, examináveis de ofício, o recurso de apelação devolve para o Órgão ad quem a matéria impugnada, que se restringe aos limites dessa impugnação. Afere-se, na espécie, ter o Órgão prolator da decisão recorrida proferido julgamento extra petita, porquanto enfrentou questões atinentes a direito patrimonial, que não constituíram objeto de insurgência." (AgRg no REsp 1006105 RS, Rel. Ministro CARLOS FERNANDO MATHIAS (JUIZ FEDERAL CONVOCADO DO TRF $1^{\mathrm{a}}$ REGIÃO), QUARTA TURMA, julgado em 12/08/2008, DJe 29/09/2008).

"Conforme ressaltado na decisão agravada, incide verdadeiramente em julgamento extra petita o enfrentamento de ofício pelo órgão julgador de questões referentes a direito patrimonial, inexistindo pedido ou recurso nesse sentido, conforme pacificado pela e. Segunda Seção, quando do julgamento do REsp n. 541.153/RS (Rel. Min. Cesar Asfor Rocha, unânime, DJU de 14.09.2005) [...]."(AgRg no REsp 1028361 RS, Rel. Ministro ALDIR PASSARINHO JUNIOR, QUARTA TURMA, julgado em 15/05/2008, DJe 16/06/2008).

"[...]Viola o princípio do tantum devolutum quantum apellatum odeferimento de repetição de indébito, em face do reconhecimento de abusividade no contrato de financiamento bancário, sem que a parte interessada tenha manejado o competente recurso de apelação. Entendimento da Segunda Seção (EResp no 702524/RS e REsp 541153/RS)." (EREsp 645902 RS, Rel. Ministro FERNANDO GONÇALVES, SEGUNDA SEÇÃO, julgado em 10/10/2007, DJ 22/10/2007, p. 189).

"Na realidade, o entendimento mais recente desta egrégia Corte é no sentido da impossibilidade do reconhecimento, de ofício, de nulidade de cláusulas contratuais consideradas abusivas, sendo, para tanto, necessário o pedido expresso da parte interessada (ut REsp 612.470/RS, relatora Ministra Nancy Andrighi, DJ 30.06.2006). Assinala-se, ainda, que, nos termos do artigo 515 do Código de Processo Civil, excetuando-se as matérias de ordem pública, examináveis de ofício, o recurso de apelação devolve para o Órgão ad quem a matéria impugnada, que se restringirá aos limites dessa impugnação. Afere-se, na espécie, ter o Órgão prolator da decisão recorrida proferido julgamento extra petita, porquanto enfrentou questões

Revista de Direito, Glob e Res. nas Rel. de Cons.| e-ISSN: 2526-0030 | Minas Gerais | v. 1 | n. 2| p. 319-334 |Jul/Dez. 2015. 
atinentes a direito patrimonial, que não constituíram objeto de insurgência." (REsp 1042903 RS, Rel. Ministro MASSAMI UYEDA, TERCEIRA TURMA, julgado em 03/06/2008, DJe 20/06/2008).

Importa notar, que, não obstante o argumento utilizado ser de índole meramente processual civil, a redação do verbete faz referência expressa à qualidade dos contratos alcançados, quais sejam os contratos bancários. Não é, portanto, coincidência alguma o fato de serem os contratos deste jaez os que maiores dissabores causam à sociedade de consumo, justamente pela abusividade de cláusulas que determinam o flagelo da onerosidade excessiva aos consumidores. Isso pode ser facilmente constatado a partir de pesquisa realizada junto ao Sistema Nacional de Informações de Defesa do Consumidor - SINDEC, do Ministério da Justiça.

Segundo o Ministério, a partir de dados do SINDEC, em uma simulação feita em todos os Estados, as reclamações de consumidores em relação aos assuntos ligados aos bancos e financeiras, representam mais de $30 \%$ do total de reclamações, sendo mais intensos os dados nos Estados mais pobres, como no Amapá, onde o percentual alcança 47,91\% do total. Eis o gráfico:

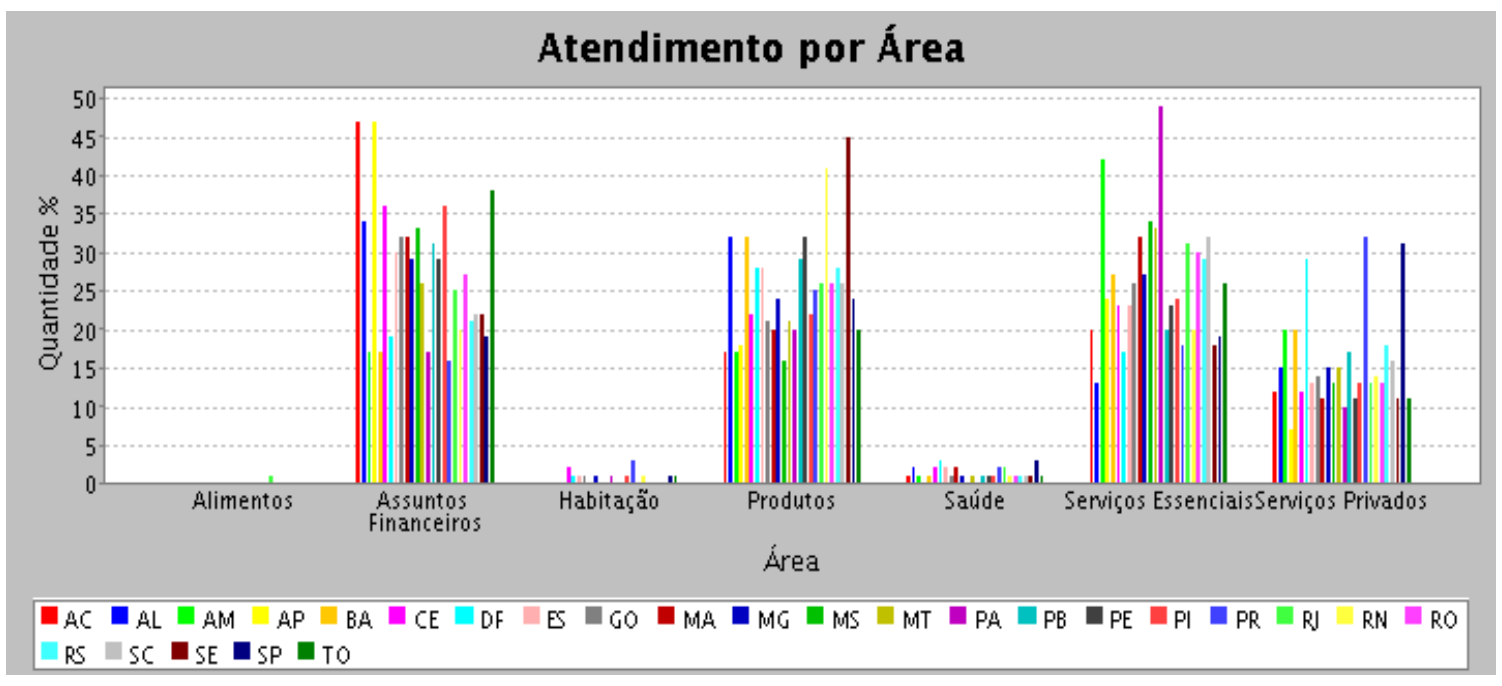

Fonte: BRASIL. Ministério da Justiça. Sistema Nacional de Informações de Defesa do Consumidor SINDEC, disponível em < http://portal.mj.gov.br/SindecNacional/>, acesso em 2 abr 2015.

Assim, é possível supor o imenso impacto negativo da referida Súmula 381 do STJ, na tutela do consumidor contratante, na medida em que os problemas relacionados às relações negociais e contratuais de natureza bancária, ocupam destaque substancial, máxime na 
economia brasileira, onde o crédito tomado de instituições bancárias ou congêneres representa um dos pilares da economia e do acesso aos bens de consumo ${ }^{3}$.

Registre-se ademais, que no atual cenário jurisdicional brasileiro, com o advento do Código de Processo Civil de $2015^{4}$, análise da súmula passa a ser relevantíssima, já que os entendimentos sumulares têm o poder, de uma forma geral, na jurisdição, de provocar a irradiação de seu conteúdo, em um movimento de verdadeiro retrocesso no tocante à ação do Estado em prol da tutela consumerista.

Vê-se, portanto, que a partir das justificativas eminentemente dogmáticas e meramente processuais utilizadas pelo STJ, podem, de fato, ocorrer antinomias no plano da legislação infraconstitucional, o que, à toda evidência, recomenda uma análise da Súmula no plano de sua constitucionalidade.

\section{FUNDAMENTOS DA PROTEÇÃO JURISDICIONAL DO CONSUMIDOR}

Por vários ângulos que se possa imaginar a atividade interpretativa de que se utilizou o STJ ao editar a Súmula 381, nenhum traço de racionalidade é possível ser encontrado, seja pelo cotejo das fontes preponderantes e especialíssimas, próprias do microssistema de defesa do consumidor, ou seja por sua própria índole constitucional, todas a recomendar uma interpretação atenta à relação de consumo e suas vicissitudes.

Daí porque se faz necessária uma abordagem mais abrangente da questão, voltada fundamentalmente para a compreensão das bases do Direito do Consumidor de forma a comprovar a fragilidade e o descompasso temporal, fenomenológico e constitucional do precedente em questionamento.

\subsection{Direito do Consumidor como Direito Humano}

\footnotetext{
${ }^{3}$ A expansão do crédito no Brasil se deu de forma excepcionalmente rápida nos últimos 10 anos. De maneira concomitante ao aumento expressivo na demanda por crédito tem ocorrido o endividamento das classes de renda mais modestas, com crescimento significativo da participação do cartão de crédito, modalidade que apresenta o maior indicador de inadimplência (SBICCA;FLORIANI; JUK, 2012, p.6).

${ }^{4}$ O Código Processual de 2015 conferiu enorme importância e efeitos práticos aos precedentes jurisprudenciais, conforme pode ser visto por alguns dos dispositivos que são adiante citados: Art. 332. Nas causas que dispensem a fase instrutória, o juiz, independentemente da citação do réu, julgará liminarmente improcedente o pedido que contrariar: I - enunciado de súmula do Supremo Tribunal Federal ou do Superior Tribunal de Justiça; [...] Art. 932. Incumbe ao relator: IV - negar provimento a recurso que for contrário a: a) súmula do Supremo Tribunal Federal, do Superior Tribunal de Justiça ou do próprio tribunal; [...] V - depois de facultada a apresentação de contrarrazões, dar provimento ao recurso se a decisão recorrida for contrária a: a) súmula do Supremo Tribunal Federal, do Superior Tribunal de Justiça ou do próprio tribunal; [...] Art. 927. Os juízes e os tribunais observarão: IV - os enunciados das súmulas do Supremo Tribunal Federal em matéria constitucional e do Superior Tribunal de Justiça em matéria infraconstitucional;
}

Revista de Direito, Glob e Res. nas Rel. de Cons.| e-ISSN: 2526-0030 | Minas Gerais | v. 1 | n. 2 | p. 319-334 |Jul/Dez. 2015. 
Ao realocar o ser humano para o centro da proteção jurídica do Estado, a Declaração Universal dos Direitos Humanos, de 1948, não deixou sem vez a questão consumerista, fazendo menção expressa à sua proteção.

Dessa forma os Direitos Sociais e Econômicos estão presentes na Declaração conforme texto do artigo XXII:

Toda pessoa, como membro da sociedade, tem direito à segurança social e à realização, pelo esforço nacional, pela cooperação internacional e de acordo com a organização e recursos de cada Estado, dos direitos econômicos, sociais e culturais indispensáveis à sua dignidade e ao livre desenvolvimento da sua personalidade.

Em 1966, veio à lume o Pacto Internacional sobre os

Direitos Econômicos, Sociais e Culturais, assim apontando já no preâmbulo:

em conformidade com a Declaração Universal dos Direitos do Homem, o ideal do ser humano livre, liberto do medo e da miséria, não pode ser realizado a menos que sejam criadas condições que permitam a cada um desfrutar dos seus direitos económicos, sociais e culturais, bem como dos seus direitos civis e políticos;

Por seu turno, a Convenção Americana de Direitos Humanos (Pacto de San José da Costa Rica), de 1969, a exemplo da própria Declaração Universal, traz em seu pórtico a repetição dos preceitos do Pacto Internacional sobre os Direitos Econômicos:

Reiterando que, de acordo com a Declaração Universal dos Direitos Humanos, só pode ser realizado o ideal do ser humano livre, isento do temor e da miséria, se forem criadas condições que permitam a cada pessoa gozar dos seus direitos econômicos, sociais e culturais, bem como dos seus direitos civis e políticos;

Resta claro que todas as macroconvenções internacionais aqui relacionadas ${ }^{5}$ se concentram no modelo de liberdade econômica com a funcionalidade de promover a dignidade da pessoa humana, através do seu acesso aos bens que lhe possam proporcionar uma existência digna.

É nesse sentido que se conformam os Direitos Sociais e Econômicos, destinados a proporcionar à pessoa humana a justiça econômica, acesso e distribuição dos recursos financeiros e de bens de consumo, retirando ou evitando qualquer tipo de marginalização ou situação de pobreza, conforme salienta Flávia Piovesan (PIOVESAN, 2013, p.162).

\footnotetext{
${ }^{5}$ O Brasil é signatário das convenções internacionais citadas no tópico 3, conforme determina o Decreto ${ }^{\circ} 591$, de 6 de Julho de 1992 (quanto ao Pacto Internacional sobre Direitos Econômicos, de 1966) e Decreto nº 678, de 6 de Novembro de 1992 (quanto ao Pacto de San José da Costa Rica, de 1966).
} 
Por certo, não há como negar que as questões afetas ao Direito do Consumidor, como é o caso dos contratos bancários a que se refere a Súmula 381, devem ter tratamento e envergadura de Direitos Humanos. Isso já recomendaria uma postula publicista do EstadoJuiz ao contrário da postura privatista esboçada no referido aresto.

Por assim ser, o enfrentamento da matéria suscita um olhar diferenciado da jurisdição quando se está diante de tais questões, porquanto elas passam a ser metas de Estado e não apenas conflitos restritos aos interesses e disponibilidades das partes envolvidas no processo. Logo, ao retirar do julgador a possibilidade de intervenção em favor do consumidor, no tocante ao reconhecimento das abusividades havidas em contratos bancários, o STJ, mitigou, por óbvio, as forças e a operacionalidade do Estado brasileiro, naquilo que ele, por mais de uma vez e em mais de um pacto internacional, se comprometeu a cumprir!

Todo esse construto em torno do sujeito consumidor leva em conta sua condição de extrema vulnerabilidade e mais completa incapacidade de reação (MARCUSE, 1967, p. 17). A impotência para reagir vulnera o consumidor e recomenda a intervenção do Estado de forma dirigista e reguladora no tocante aos pactos, o que não exclui os contratos bancários, máxima por serem os mais lesivos.

A Súmula 381, portanto, é violadora de direito fundamental consistente em poder receber uma prestação positiva do Estado, consistente na tutela jurisdicional interventiva nos pactos. É o que se destaca das observações de Robert Alexy, ao tratar dos direitos a ações positivas:

\begin{abstract}
Especialmente intensa é a discussão sobre os assim chamados direitos fundamentais sociais, como, por exemplo, direitos à assistência social, ao trabalho, à moradia e à educação (ALEXY, 2012, p. 434). Enquanto direitos subjetivos, todos os direitos a prestações são relações triádicas entre um titular do direito fundamental, o Estado e uma ação estatal positiva (ALEXY 2012, p. 445).
\end{abstract}

De outro lado, o entendimento do STJ esboçado na Súmula, deixa bem claro que um dos fundamentos de seu famigerado verbete sumular se situa na disponibilidade dos direitos tratados nos contratos, revelando sua contaminação com os ideias liberalistas.

A jurisdição, em matéria de consumo, deve deslocar o seu olhar das concepções meramente patrimoniais e individualistas, inclusive no campo processual, especialmente quando a Constituição Federal, rompe o paradigma do individualismo egoísta, rumando ao propósito de construir uma sociedade mais justa, tal como prevê os Objetivos Fundamentais, que são também da jurisdição (BRASIL, 1988).

Sobre isso, convém trazer à colação o pensamento de Pietro Perlingieri 
Em um ordenamento que se caracteriza pela socialidade e que legitima a superação individualista do indiferente jurídico (cfr. retro, cap. $5^{\circ} \S 62$ ), o próprio regime jurídico - ainda que representado por princípios e não por normas regulamentares deve concernir às utilidades individuais e sociais. Isso permite considerar juridicamente relevantes não somente os bens patrimoniais, mas também aqueles que são protegidos prescindindo da própria relevância econômica. A relevância pode-se configurar também no regime de circulação do bem, das modalidades de acesso, ou seja no regime de vicissitudes que lhe interessam (PERLINIGIERI, 2007, p. 236)..

Dessa forma, a Súmula 381 viola Direito Humano, na medida em que afasta o Estado da tutela dos Direitos Sociais e Econômicos, deixando de levar em conta a natureza irrenunciável de que são revestidas as questões consumeristas e o poder/dever de atuação do Estado.

\subsection{Direito do Consumidor e a Constituição Federal de 1988}

$\mathrm{Na}$ esteira dos discursos humanistas e das projeções internas dos pactos celebrados pelo Brasil, voltados, dentre outras coisas, para a tutela dos Direitos Sociais e Econômicos, a Constituição Federal de 1988, em matéria de Direito do Consumidor, destinou especial atenção ao tema, especialmente ao colocar a tutela jurídica das relações entre consumidores e fornecedores como dever do próprio Estado.

Logo, ao contrário do entendimento sumular do STJ, por força constitucional, o Estado, inclusive o Estado-Juiz, deverá tomar partido das questões afetas à proteção do consumidor, o que alcança também os contratos, já que não houve qualquer restrição ao preceito protetivo, que é geral, por excelência. Vejamos:

Art. $5^{\circ}$ Todos são iguais perante a lei, sem distinção de qualquer natureza, garantindose aos brasileiros e aos estrangeiros residentes no País a inviolabilidade do direito à vida, à liberdade, à igualdade, à segurança e à propriedade, nos termos seguintes: [omissis]

XXXII - o Estado promoverá, na forma da lei, a defesa do consumidor; (BRASIL, 1988)

Come efeito, a remissão constitucional à proteção do estatal nos termos da lei foi levada bastante a sério pelo constituinte originário, tanto que fez prever no artigo 48, dos Atos das Disposições Constitucionais Transitórias, o prazo de 120 para elaboração de projeto do que viria a ser o Código de Defesa do Consumidor. 
Logo, ainda mesmo no plano da legislação ordinária, qualquer interpretação que se faça acerca de matérias sujeitas ao alcança das leis que regem o consumo e o fornecimento, deve ser levado em conta que todas elas, especialmente o Código de Defesa do Consumidor, são na verdade, um desdobramento da vontade do constituinte originário.

\subsection{Direito do Consumidor e o Código de Defesa do Consumidor de 1990}

A partir do mandamento constitucional o Código de Proteção e Defesa do Consumidor foi alçado ao ordenamento jurídico brasileiro por obra da Lei $n^{\circ}$ 8.078/90, CDC, que já no seu artigo inaugural deu a tônica de sua envergadura e natureza se afirmando como norma de ordem pública: "Art. $1^{\circ} \mathrm{O}$ presente código estabelece normas de proteção e defesa do consumidor, de ordem pública e interesse social, nos termos dos arts. $5^{\circ}$, inciso XXXII, 170, inciso V, da Constituição Federal e art. 48 de suas Disposições Transitórias."

A partir da interpretação gramatical do texto do CDC já seria possível coroar de absurdo o entendimento externado pela Súmula 381, na medida que, em se tratando os contratos celebrados entre consumidores e bancos como matérias jurídicas submetidas a uma ordem pública inderrogavel por vontade das partes, o julgador está autorizado a conhecer de ofício de questões que não foram suscitadas pelas partes. O próprio STJ assim o faz quando invalida de ofício a cláusula de eleição de foro diverso do domicílio do consumidor, senão vejamos:

AGRAVO REGIMENTAL EM AGRAVO EM RECURSO ESPECIAL. AÇÃO DE COBRANÇA. CORRETORA DE BOLSA DE VALORES. COMPETEENCIA. FORO DO CONSUMIDOR. RELAÇÃO DE CONSUMO. REVISÃO. SÚMULA 5 E 7 DO STJ.

1. Nos contratos de adesão, o foro de eleição contratual cede em favor do local do domicílio do devedor, sempre que constatado ser prejudicial à defesa do consumidor, podendo ser declarada de ofício a nulidade da cláusula de eleição pelo julgador. Precedentes.

2. [omissis]

3. Agravo regimental não provido.

(BRASIL, Superior Tribunal de Justiça. AgRg no AREsp 476.551/RJ, Rel. Ministro LUIS FELIPE SALOMÃO, QUARTA TURMA, julgado em 25/03/2014, DJe 02/04/2014)

Ainda, no tocante às questões de ordem pública, temos que, segundo o STJ

PROCESSUAL CIVIL. AGRAVO REGIMENTAL NO RECURSO ESPECIAL. COISA JULGADA. MATÉRIA DE ORDEM PÚBLICA. EFEITO TRANSLATIVO.APLICABILIDADE AOS RECURSOS ORDINÁRIOS.

1. .[omissis] 
2. A jurisprudência desta Corte firmou-se no sentido de que as instâncias ordinárias podem conhecer ex officio de matéria de ordem pública, em respeito ao efeito translativo dos recursos ordinários e ao princípio da economia processual, possibilitando, inclusive, a extinção do feito principal sem resolução do mérito. 3. Agravo regimental a que se nega provimento.

(BRASIL, Superior Tribunal de Justiça. AgRg no REsp 1306712/PR, Rel. Ministro OG FERNANDES, SEGUNDA TURMA, julgado em 26/08/2014, DJe 10/09/2014)

Porque então o mesmo STJ que enfrenta a questão da abusividade da cláusula de eleição de foro sob a perspectiva de seu conhecimento de ofício edificou tratamento sui generis destinado aos contratos bancários? E por que justamente em relação aos contratos bancários?

Certamente o enunciado sumular não faz o menor sentido. É que o centro do raciocínio do Superior Tribunal está na impossibilidade de conhecimento da abusividade de ofício em função do que determina o artigo 515, do Código de Processo Civil, o qual trata do efeito devolutivo do recurso de apelação. Eis o texto do artigo: " A apelação devolverá ao tribunal o conhecimento da matéria impugnada."(BRASIL, Código de Processo Civil, 2014).

Acontece que, nem mesmo sob tal ótica, é possível se observar qualquer justificativa jurídica para o enunciado, uma vez que as questões de ordem pública, não só podem, como também devem ser conhecidas de ofício, máxime porque o Estado tem o poder/dever de intervir em tais questões e o juiz é o instrumento de execução da jurisdição estatal.

Olvidando-se de causas menos nobres motivadoras do enunciado 381, fica clara a tradição liberalista, individual e patrimonialista ainda impregnada na Corte Superior!

Como evidencia a melhor doutrina, a tradição do processo civil sempre apontou para uma ação individual, estando "deslocado", quando o assunto é tutela de massas (MANCUSO,1994, p.192). E a tutela do consumidor, embora feita no âmbito de um processo individual, sempre tem tônica coletiva, a partir da própria noção de massificação dos contratos, ou seja, o mesmo contrato pode render para milhares de consumidores o mesmo malefício decorrente da mesma ou das mesmas cláusulas abusivas.

É também essa a observação de César Fiúza e Giordano Bruno Soares Roberto ao analisarem que "foi a produção em massa que exigiu a comercialização em massa dos produtos, fazendo com que a contratação perdesse, sistematicamente, o caráter de livre e demorada negociação para ganhar caráter mais geral.” (FIÚZA; ROBERTO, 2002, p.56).

Mas, além disso, convém trazer a colação o que o próprio Código Civil, já nascido num ambiente de feição constitucional, aponta, quanto ao regimento das nulidades nos negócios jurídicos:

Revista de Direito, Glob e Res. nas Rel. de Cons.| e-ISSN: 2526-0030 | Minas Gerais | v. 1 | n. 2| p. 319-334 |Jul/Dez. 2015. 
Art. 168. As nulidades dos artigos antecedentes podem ser alegadas por qualquer interessado, ou pelo Ministério Público, quando lhe couber intervir.

Parágrafo único. As nulidades devem ser pronunciadas pelo juiz, quando conhecer do negócio jurídico ou dos seus efeitos e as encontrar provadas, não lhe sendo permitido supri-las, ainda que a requerimento das partes. (BRASIL, Código Civil. 2014)

Sobre o alcance de tal dispositivo, Cesar Fiúza afirma categoricamente que "caberá ao juiz pronunciá-las de ofício se delas tomar conhecimento". (FIÚZA, 2013, p. 307).

Não é demais ressaltar, nesse trilho, que as cláusulas contratuais ditas abusivas, violam a ordem jurídica, razão pela qual são expressamente proibidas pelo CDC, conforme a Seção II, Das Cláusulas Abusivas: " Art. 51. São nulas de pleno direito, entre outras, as cláusulas contratuais relativas ao fornecimento de produtos e serviços que:". (BRASIL. Código de Defesa do Consumidor, 2014)

Assim, o argumento sustentado pelo STJ encontra-se superado por toda a ordem jurídica e principiológica que se estabeleceu no Brasil, especialmente após a Constituição Federal de 1988, tendo o Estado se comprometido a uma série de programações que perpassam pela atuação da jurisdição, como é o caso da defesa e da proteção do consumidor, assim como de toda a Ordem Econômica Constitucional.

\subsection{Necessidade de uma visão pós-positivista}

A tutela contratual do consumidor nos contratos de consumo, envolve uma miríade de posturas que tem ou devem ter caráter efetivo, sob pena da proteção não passar de um discurso vazio ou meramente simbólico.

É preciso que o Estado-Juiz, assuma, sem medo e com prontidão, o papel de anular contratos e cláusulas, tão logo verifique seu caráter abusivo ou sua discrepância com a equivalência material, independente de apontamento específico no processo civil.

A meta da jurisdição é tutelar a relação jurídica como um todo, da forma mais abrangente possível e sem as amarras da congruência ou adstrição, totalmente voltadas ao ambiente processual privado e nada consentâneas com um processo de viés públicoprogramático de defesa do consumidor.

Se a proteção do consumidor está a cargo do Estado, o Estado-Juiz deve fazê-la no sentido mais eficiente possível. Robert Alexy chega a mencionar que os princípios são mandamentos de otimização (ALEXY, 2012, p.90). 
Não há que se ter tantas reservas à intervenção de ofício do juiz quanto se tem claro um cenário de efetiva dominação do consumidor. Nos contratos de longa duração, por exemplo, é preciso se verificar a quem aproveita a manutenção do pacto e se há compartilhamento justo de benefícios, pois, do contrário, a determinação do fim do pacto é medida que se impõe.

No tocante aos juros, inclusive os remuneratórios, devem ser objeto de atenção específica do Estado-Juiz, porque neles se concentram boa parte das violações aos direitos econômicos dos consumidores e a própria agressividade do mercado é neles projetada.

Os encargos da mora que determinam, muitas vezes, a onerosidade excessiva do contrato, deve ser combatida com veemência, porque, dentre outras coisas, são materialmente injustas e sua estipulação é unilateral e impositiva, sem qualquer espaço dialógico.

Mais que isso, a finalidade dos contratos e, especificamente, dos contratos de consumo, nunca foi a de aprisionar, por qualquer forma, máxime a econômica, o consumidor. Por isso, em sentido amplo, toda forma de exercício injusto ${ }^{6}$ de contrato deve ser combatida pela ação jurisdicional e a Súmula 381 do STJ se coloca na contramão da evolução jurídica em nítido posicionamento de retrocesso quanto à tutela de um Direito Humano!

É preciso um olhar da jurisdição que dê realce aos objetivos da ordem econômica através de uma interpretação pós-positivista, atenta ao estabelecimento de uma tutela libertária do consumidor, especialmente quando estes se encontram vinculados por pactos danosos aos seus direitos.

Portanto, o pensamento do STJ é estritamente positivista e sua negação encontra respaldo no pensamento de Lucas Gontijo.(GONTIJO, 2011, p129) ${ }^{7}$

Por seu turno, Ricardo Luis Lorenzetti, coloca a questão do papel da jurisdição sob a ótica da justiça distributiva, para que se observe o contrato em função dos seus reflexos econômicos. Essa abordagem somente é possível no sistema pós-positivista, advertindo Lorenzetti a observância da decisão sob uma conjunção de aspectos tais como a garantia de igualdade, os reflexos contratuais sobre os demais consumidores e, por fim, a estrutura do sistema como um todo. (LORENZETTI, 1998, p.554).

Ainda segundo Ricardo Lorenzetti, desta vez em outra obra, é necessária uma série de posturas do Estado-Juiz, como por exemplo, a relativização dos pactos, a interpretação

\footnotetext{
${ }^{6}$ No sentido da violação normativa ou do abuso de direito.

${ }^{7}$ A teoria antipositivista apresentada não pretende chegar ao limite de um, por assim dizer, desconstrutivismo jurídico. Procura-se tão-somente, flexibilizar a rigidez dos métodos de conhecimento e a aplicação do direito, a fim de trazer maior aproximação deste com as pelejas humanas. Busca-se, pois, particularizar a aplicação dos métodos jurídicos e mantê-los atentos às possíveis exigências peculiares de cada caso (2011, p. 129).
} 
favorável das cláusulas contratuais duvidosas em favor do consumidor, a nulidade das cláusulas e pactos que, mesmo consentidas, revelem abusos, bem como o estabelecimento de uma igualdade material subjetiva e quanto à fruição e onerosidade do objeto do contrato (LORENZETTI, 2011, p.47).

Enzo Roppo, nessa linha, observa que há uma tendência a exigir uma nova postura do juiz perante o enfrentamento das demandas que versam sobre contratos. Para ele esse movimento:

corresponde a um fenômeno - que parece caracterizar muitos ordenamentos contemporâneos - de ampliação dos poder do juiz e de exaltação de sua capacidade de valorar factos e situações de modo responsável e outónomo, à luz de princípios gerais mais do que em aplicação mecânica de previsões legais analíticas e casuísticas. (ROPPO, 2009, p.175)

E o que praticou o STJ e vem praticando a partir da Súmula 381, nada mais é do que uma demonstração de retrocesso do Tribunal, conforme o próprio Roppo argumenta:

\begin{abstract}
A teoria política do "contratualismo" mostra, assim, à evidência como o conceito de contrato pode ser utilizado, e foi historicamente utilizado, com uma função ideológica, quer dizer - uma vez que é este o significado técnico de "ideologia" com uma função de parcial ocultamento ou disfarce da realidade, operado com o fim de melhor prosseguir ou tutelar determinados interesses. Mas isso resulta ainda mais claramente, e para nós mais significativa e relevantemente, se analisarmos as doutrinas e os princípios em matéria de contrato elaborados pela ciência jurídica e codificados pelos legisladores a partir do século passado, no apogeu da hegemonia política cultural da classe burguesa, e que - embora de várias formas contestados e abalados, - ainda hoje continuam a exercer a sua influência. (ROPPO, 2009, p. 29-30)
\end{abstract}

Portanto é preciso que o Estado se faça forte e não ceda aos caprichos daqueles que dominam e detém o capital. Daí porque declarar Hannah Arendt sua desconfiança nos ideais econômicos liberais, que pressupõem a liberdade a partir da apropriação de bens e da defesa da propriedade privada. Para ela, as liberdades somente estarão seguras se tuteladas pelo Estado (ARENDT, 2013, p.83). Esse é o papel da jurisdição em matéria de consumo.

\title{
4. CONCLUSÃO
}

A Súmula 381, do STJ, viola Objetivo Fundamental da República ao limitar a ação da justiça no sentido da possibilidade de sua atuação em prol da proteção dos interesses econômicos dos vulneráveis. 
O enunciado também viola o Direito Fundamental subjetivo de proteção (direito a uma prestação positiva por parte do Estado), bem como impõe limitações à jurisdição para que ela possa cumprir seu dever constitucional de tutela do consumidor.

Mais que isso a referida súmula viola o conteúdo público e a natureza social do Código de Defesa do Consumidor, especialmente quando este diploma prevê a nulidade das cláusulas abusivas e a possibilidade de intervenção de ofício do Estado para debelá-la.

Ademais, o entendimento sumular estudado no presente artigo, é jurisprudência contra legem, ainda que analisado sob o prisma eminentemente privado, na medida em que determina limitação da atuação jurisdicional contrária ao que previsto no Código Civil Brasileiro, no tocante à postura do juiz diante do negócio jurídico maculado pela nulidade, como é o caso das cláusulas abusivas nos contratos de consumo.

Por fim, o sistema normativo de defesa do consumidor é fundado em cláusulas abertas justamente para permitir ao juiz maiores possibilidades de fazer face aos fenômenos que surgem, a todo momento, com rapidez e complexidades impensadas. Nesse sentido, o teor da Súmula 381 se opõe radicalmente a essa tendência vital para a proteção do consumidor na contemporaneidade.

\section{REFERÊNCIAS}

ALEXY, Robert. Teoria dos Direitos Fundamentais. 2. ed.Tradução: Virgílio Afonso da Silva. São Paulo: Malheiros Editores, 2012.

ARENDT, Hannah. A Condição Humana. Tradução: Roberto Raposo. - 11. ed. - Rio de Janeiro: Forense Universitária, 2013.

BRASIL, Código Civil. Lei $\mathrm{n}^{\circ}$ 10.406, de 10 de janeiro de 2002. Disponível em: <http://www.planalto.gov.br/ccivil_03/leis/2002/110406.htm>. Acesso em: 10 dez. 2014.

BRASIL, Constituição (1988). Constituição da República Federativa do Brasil. Brasília, DF, Disponível em: <http://www.planalto.gov.br/ccivil_03/constituicao/constituicao.htm>. Acesso em: Acesso em: 10 dez. 2014.

BRASIL. Código Civil. Lei n. 3.071, de $1^{\circ}$ de janeiro de 1916.. Disponível em: < http://www.planalto.gov.br/ccivil_03/leis/13071.htm>. Acesso em: 10 dez. 2014.

BRASIL. Código de Defesa do Consumidor. Lei $\mathrm{n}^{\circ}$ 8.078, de 11 de setembro de 1990.Disponível em: < http://www.planalto.gov.br/ccivil_03/leis/18078.htm>. Acesso em: 10 dez. 2014. 
BRASIL. Código de Processo Civil. Lei no 5.869, de 11 de janeiro de 1973. Disponível em: < http://www.planalto.gov.br/ccivil_03/leis/15869compilada.htm>. Acesso em: 10 dez. 2014.

BRASIL. Superior Tribunal de Justiça. Súmula 381, SEGUNDA SEÇÃO, julgado em 22/04/2009, DJe 05/05/2009. Disponível em < http://www.stj.jus.br/SCON/pesquisar.jsp> Acesso em 02 abr 2015.

BRASIL, Superior Tribunal de Justiça. AgRg no REsp 782895 SC, Rel. Ministro SIDNEI BENETI, TERCEIRA TURMA, julgado em 19/06/2008, DJe 01/07/2008. Disponível em http://www.stj.jus.br/SCON/jurisprudencia/toc.jsp?tipo_visualizacao=null\&processo $=782895$ $+\& b=$ ACOR \& thesaurus=JURIDICO > Acesso em 02 abr 2015.

BRASIL, Superior Tribunal de Justiça. AgRg no REsp 1006105 RS, Rel. Ministro CARLOS FERNANDO MATHIAS (JUIZ FEDERAL CONVOCADO DO TRF $1^{\mathrm{a}}$ REGIÃO), QUARTA TURMA, julgado em 12/08/2008, DJe 29/09/2008. Disponível em http://www.stj.jus.br/SCON/jurisprudencia/toc.jsp?tipo_visualizacao=null\&processo $=100610$ $5 \& \mathrm{~b}=$ ACOR\&thesaurus=JURIDICO > Acesso em 02 abr 2015.

BRASIL, Superior Tribunal de Justiça. Rel. Min. Cesar Asfor Rocha, unânime, DJU de 14.09.2005) [...]."(AgRg no REsp 1028361 RS, Rel. Ministro ALDIR PASSARINHO JUNIOR, QUARTA TURMA, julgado em 15/05/2008, DJe 16/06/2008. Disponível em $<$ http://www.stj.jus.br/SCON/jurisprudencia/toc.jsp?tipo_visualizacao=null\&processo $=10283$ $61 \& b=$ ACOR\&thesaurus=JURIDICO $>$ Acesso em 02 abr 2015.

BRASIL, Superior Tribunal de Justiça. EREsp 645902 RS, Rel. Ministro FERNANDO GONÇALVES, SEGUNDA SEÇÃO, julgado em 10/10/2007, DJ 22/10/2007. Disponível em $<$ http://www.stj.jus.br/SCON/jurisprudencia/toc.jsp?tipo_visualizacao=null\&processo $=64590$ $2 \& b=A C O R \&$ thesaurus=JURIDICO $>$ Acesso em 02 abr 2015.

BRASIL, Superior Tribunal de Justiça. REsp 1042903 RS, Rel. Ministro MASSAMI UYEDA, TERCEIRA TURMA, julgado em 03/06/2008, DJe 20/06/2008. Disponível em $<$ http://www.stj.jus.br/SCON/jurisprudencia/toc.jsp?tipo_visualizacao $=$ null\&processo $=10429$ $03 \& b=$ ACOR \& thesaurus=JURIDICO $>$ Acesso em 02 abr 2015.

BRASIL, Superior Tribunal de Justiça. AgRg no AREsp 476.551/RJ, Rel. Ministro LUIS FELIPE SALOMÃO, QUARTA TURMA, julgado em 25/03/2014, DJe 02/04/2014. Disponível em $<$ http://www.stj.jus.br/SCON/jurisprudencia/toc.jsp?tipo_visualizacao=null\&processo $=47655$ $1 \& \mathrm{~b}=\mathrm{ACOR} \&$ thesaurus=JURIDICO $>$ Acesso em 02 abr 2015.

BRASIL, Superior Tribunal de Justiça. AgRg no REsp 1306712/PR, Rel. Ministro OG FERNANDES, SEGUNDA TURMA, julgado em 26/08/2014, DJe 10/09/2014. Disponível em

http://www.stj.jus.br/SCON/jurisprudencia/toc.jsp?tipo_visualizacao=null\&processo $=13067$ 12\&b=ACOR\&thesaurus=JURIDICO Acesso em 02 abr 2015. 
FIÚZA, César Roberto; ROBERTO, Giordano Bruno Soares. Contratos de adesão. Belo Horizonte: Mandamentos, 2002.

FIUZA, César. Direito Civil: curso completo. 16. ed. Belo Horizonte: Del Rey, 2013.

GONTIJO, Lucas de Alvarenga. Filosofia do direito: metodologia jurídica, teoria da argumentação e guinada linguístico-pragmática. Belo Horizonte: Arraes Editores, 2011.

LORENZETTI, Ricardo Luis. Fundamentos do Direito Privado. São Paulo: RT, 1998.

LORENZETTI, Ricardo Luis. Teoria da decisão judicial: fundamentos de Direito. São Paulo: RT, 2011.

MANCUSO, Rodolfo de Camargo. Interesses Difusos: conceito e legitimação para agir. 3. ed. São Paulo: Editora Revista dos Tribunais, 1994.

MARCUSE, Herbert. Ideologia da Sociedade Industrial. Trad. Giasone Rebuá. - Rio de Janeiro: Zahar, 1967.

OEA. Comissão Interamericana de Direitos humanos. Convenção Americana de Direitos Humanos, adotada em 22 de novembro de 1969. Disponível em <http://www.oas.org/dil/esp/tratados_B32_Convencion_Americana_sobre_Derechos_Human os.htm> Acesso em 10 dez. 2014.

ONU. Assembleia Geral das Nações Unidas. Declaração Universal dos Direitos Humanos, adotada em 10 de dezembro de 1948.Disponível em:<http://unicrio.org.br/img/DeclU_D_HumanosVersoInternet.pdf> Acesso em 10 dez. 2014.

ONU. Assembleia Geral das Nações Unidas. Pacto Internacional sobre os Direitos Econômicos, Sociais e Culturais, adotado em 16 de dezembro de 1966.Disponível em <http://www.unfpa.org.br/Arquivos/pacto_internacional.pdf> Acesso em 10 dez. 2014.

PERLINGIERI, Pietro. Perfis do Direito Civil: introdução ao direito civil constitucional. 3. ed. Tradução: Maria Cristina de Cicco. Rio de Janeiro: Renovar, 2007.

PIOVESAN, Flávia. Direitos Humanos e o Direito Constitucional Internacional. 14. ed. São Paulo: Saraiva, 2013.

ROPPO, Enzo. O contrato.Trad. Ana Coimbra e M. Januário C. Gomes. Coimbra: Almedina, 2009.

SBICCA, Adriana; FLORIANI, Vinícius; JUK, Yohanna. Expansão do crédito no Brasil e a vulnerabilidade do consumidor. In Revista Economia \& Tecnologia (RET). v. 8, n. 4, p. 0516, Out/Dez 2012 (ISSN 2238-4715)

Revista de Direito, Glob e Res. nas Rel. de Cons.| e-ISSN: 2526-0030 | Minas Gerais | v. 1 | n. 2 | p. 319-334 |Jul/Dez. 2015. 